\title{
Identity, Competitors \& Distinctiveness: Who Are We? Who Are They?
}

\author{
W. Timothy Few \\ Edinboro University; Core Strategies LLC \\ Molly E. Few \\ Core Strategies LLC \\ Author's Note \\ Correspondence concerning this article should be addressed to: wfew@edinboro.edu and
}

W. Timothy Few; Edinboro University; Core Strategies LLC

Molly E. Few; Core Strategies LLC molly@ corestrategies.us.

\begin{abstract}
Organizational identity has emerged as an important theoretical concept. However, our understanding of distinctiveness is inadequate since this aspect of organizational identity has received limited research attention. Accordingly, this paper reports the results of a qualitative study designed to explore how managers construe their organization's identity distinctiveness. Based on this study's findings, this paper furthers our knowledge of organizational identity by presenting a theoretical model depicting how identity distinctiveness is construed. Overall, the results of this study suggest that managers construct an internal story - via markets, competencies and intangible identity attributes - which they believe both legitimates and distinguishes their organization.
\end{abstract}

Keywords: Organizational Identity, Distinctiveness, Legitimacy and Competition

\section{Introduction}

Over the past few decades, researchers have demonstrated the theoretical significance of organizational identity (OI) by demonstrating OI's impact on sensemaking, organizational change, strategic issue interpretation, organizational learning and competitive rivalry (Corley \& Gioia, 2003; Dutton \& Dukerich, 1991; Dutton \& Penner, 1993; Gioia \& Thomas, 1996; Livengood \& Reger, 2010). Despite these contributions, the distinctiveness element of OI has been relatively understudied (Corley et al., 2006; Gioia, Patvardhan, Hamilton, \& Corley, 2013). 


\section{IDENTITY, COMPETITORS AND DISTINCTIVENESS}

Such an oversight is significant since distinctiveness is an essential and fundamental component of OI (Whetten, 2006). Accordingly, the purpose of this paper is to contribute to the OI distinctiveness literature by exploring how top managers use competitors as reference points when developing their organizational identity distinctiveness (OID). As will be revealed, this investigation elicited two key findings. First, while an organization may operate in multiple competitive markets, it is the organization's most important markets that serve as the identity domain where managers construed their OID (Livengood \& Reger, 2010). Second, managers construct OID by forming a narrative that customers within the identity domain perceive the organization to be more legitimate than its competitors (Glynn, 2008; Suchman, 1995)

The remainder of this paper is structured as follows. First, OI is further defined and literature pertaining to OID is reviewed. Next, the qualitative research methodology employed to investigate OID is described, followed by a report of the study's findings. Last, the study's significance and practical implications are discussed.

\section{Literature Review}

At its most basic level, OI can be construed as an ongoing process of identity work in which members seek to make sense of their organization and socially construct (or reconstruct) who they are (Ashforth \& Mael, 1996; Kreiner, Hollensbe, Sheep, Smith, \& Kataria, 2015; Reger et al., 1998; Weick, 1995). As a result of these processes, an organized and shared theory of OI emerges in the form of a cognitive map (Dutton \& Penner, 1993; Fiol \& Huff, 1992) or narrative (A. D. Brown, 2006) which captures members' beliefs about the organization's central and enduring features - whether tangible (markets, competencies, products, etc.) or intangible (mission, aspirations, culture, rituals, values, ideologies, purpose, norms, management philosophy, etc.) - which enables them to meaningfully distinguish the organization from other firms (Albert \& Whetten, 1985; Corley, 2004; Gustafson \& Reger, 1995) and explain the organization's reason for existence (Ashforth \& Mael, 1996).

Building on these notions, existing theory frames the construction of OID as a process where members seek to develop optimal distinctiveness (Brewer \& Roccas, 2001; Gioia et al., 2013). Accordingly, much of what we know about OID has been elicited through research designed to explore identity formation processes (Gioia et al., 2013). These studies have developed theoretical models designed to explain how new organizations - such as entrepreneurial ventures (Navis \& Glynn, 2011; Snihur, 2016), a new school within a university setting (Gioia, Price, Hamilton, \& Thomas, 2010) and new organizations within a new industry (Clegg, Rhodes, \& Kornberger, 2007) - interact with various stakeholders (S. G. Scott \& Lane, 2000) within their identity domain (Livengood \& Reger, 2010) - the market space where an organization constructs and reconstructs its identity - in an effort to negotiate and establish their OI. As highlighted in the studies new organizations face the unique challenge of constructing OI in the face of the need to appear similar to other organizations in order to attain legitimacy, while at the same time appearing different in order to establish its OID (Cornelissen, Haslam, \& Balmer, 2007; Deephouse, 1999). Members establish similarity by locating their organization within an industry categorization scheme and affiliate the organization with other similar types of firms (Albert \& Whetten, 1985; Porac \& Thomas, 1990). This ability to categorize and affiliate is important since it enables members to make sense of 'who they are' by identifying their firm as a particular type of 


\section{IDENTITY, COMPETITORS AND DISTINCTIVENESS}

organization and adopting those characteristics that define such firms within the category. These categorization and mimicking processes, which lead to isomorphism, enable the organization to be perceived by its stakeholders as legitimate or credible (Deephouse, 1999). Whether an organization is believed to be legitimate or not depends upon the opinions and assumptions of an organization's stakeholders (W. R. Scott, 2001). Organizations are concerned about stakeholder perceptions since the extent to which an organization is viewed as legitimate has an effect on the degree to which stakeholders believe that an organization is appropriate and, hence, worthy of their continued support (Ashforth \& Gibbs, 1990). In order to be seen as legitimate by its stakeholders, organizations may align their activities with what is socially acceptable and pursue objectives in a manner that is proper or consistent with how things should and ought to be done (Ashforth \& Gibbs, 1990; W. R. Scott, 2001). In other words, stakeholders place normative pressure on organizations to conform, which prompts organizations to configure their internal activities and objectives to match stakeholders' expectations or views as to what is appropriate and proper (Ashforth \& Gibbs, 1990; W. R. Scott, 2001).

Despite the imperative to gain legitimacy, an organization's members must also establish the organization's distinctiveness in order to construct the OI (Gioia et al., 2013). Research suggests that members construct their OID in two ways. First, while an organization may gain legitimacy by aligning itself with other similar firms, categorization also provides members with the ability to distinguish the organization from those residing outside of the category (Clegg et al., 2007; Elsbach \& Kramer, 1996; Peteraf \& Shanley, 1997). For example, if the members consider their organization to be a grocery store, then this categorization enables them to distinguish their organization from other types (i.e., categories) of organizations such as convenience stores. Second, members will also distinguish their organization from those they have affiliated with in order to gain legitimacy (Gioia et al., 2013; Whetten, 2006). In order to accomplish this objective, theory suggests that members evaluate their organization and other firms on relevant dimensions of comparison that enable them to socially construct and make sense of the organization's identity distinctiveness (Jetten, Spears, \& Postmes, 2004). Members will utilize these dimensions of comparison to distinguish the organization in a positive manner, which provide members with the perception that their organization is better or possesses a higher status than comparison organizations (Elsbach \& Kramer, 1996; Jetten, Spears, \& Manstead, 1999; Jetten et al., 2004). In their 10-year qualitative study of the Episcopal church, Kreiner et al. (2015, p. 1002) found that liberal church members referenced, "so-called 'inclusive' trends in society toward greater tolerance of homosexuality" as a means to enhance their OID along the inclusiveness dimension by arguing that taking the lead in accepting gays into the church is not only consistent with the churches' OI but also would distinguish them from other Christian organizations who did not embrace such inclusiveness. In addition, members may also employ eclectic and uncommon dimensions in order to establish a positive and distinct identity (Albert \& Whetten, 1985). For example, members may choose dimensions of comparison that provide them with the ability to construct negative comparisons which provide members with the ability determine 'who they are not' and establish OID by dis-identifying or disassociating the organization from other firms (Gioia et al., 2013; Kroezen \& Heugens, 2012).

\section{Summary}

Building on prior research, this study was guided by the question: How do top managers 


\section{IDENTITY, COMPETITORS AND DISTINCTIVENESS}

perceive their organization's identity distinctiveness? Accordingly, this study employed qualitative methodologies and cognitive mapping techniques that enabled the ability to explore top managers' perceptions of their organization's identity distinctiveness. These methodologies were chosen because they provided the means to build theory and construct a theoretical model, grounded in the data, that would enhance our understanding of OID (Strauss \& Corbin, 1998). Several reasons support the design of this study. First, it was believed that studying top managers would reveal useful insights since they are viewed by researchers as playing a principle role in the ongoing process of the social construction of OI, as their leadership role positions them as sense-givers who help other organizational members make sense of the OI (Gioia \& Chittipeddi, 1991). Second, since OI is considered an organizational-level concept, previous studies were designed to explore OI at the organization or group level and, thus, took more of a process view. Conversely, this study takes a different tack by exploring OI at the individual-level. Despite OI being recognized as an organization- level construct, scholars have suggested that OI can be investigated at the individual- level since each member will possess and construct individual representations of the OI (Ashforth, Rogers, \& Corley, 2011). Furthermore, organizational identity work can be construed as an ongoing interaction of members' individual OI perceptions and beliefs. Consequently, it was believed that investigating OID at the individual-level would not only add a unique perspective but also would also provide the ability to integrate its findings into extant theory and provide some insights as to how OID is socially constructed (Eisenhardt, 1989). Based on these objectives, the methods adopted for this investigation are described in the next section.

\section{Methods}

This study employed a qualitative methodology in which top managers from various organizations were interviewed to discover how they construe OID. Qualitative methods were utilized since they provided the means to examine managers' interpretation processes, thus facilitating the ability to study and understand OID from the manager's perspective (Miles \& Huberman, 1994). In order to fully understand participants' interpretation processes, two cognitive mapping techniques were employed: the repertory grid technique (RGT) (Fransella, Bell, \& Bannister, 2004) and an organizational identity mapping technique (Dutton \& Dukerich, 1991; Fiol \& Huff, 1992; Gustafson \& Reger, 1995). Additionally, a multiple case study format was used as part of a replication strategy in which each case (i.e., participant) is considered an experiment that is used to test and refine the emerging theory (Yin, 2003). Accordingly, the objective in employing this strategy was to increase confidence in the findings by producing a theoretical understanding of OID that best fit each of the cases (Eisenhardt, 1989).

\section{Sample}

Top managers from the financial services industry were recruited for this study, as the deregulation of the financial services industry has created a significant increase in the amount of industry competition, providing a ripe opportunity for studying OID (Morrow, 2001). Participants were selected from a single industry to provide a degree of similarity among participants. However, to ensure a certain degree of difference in the final sample (Yin, 2003), 


\section{IDENTITY, COMPETITORS AND DISTINCTIVENESS}

participants were chosen from various top management positions, firm types, and firm sizes. In the end, 15 top managers were interviewed from twelve different firms in the financial services industry. Data collection efforts ceased after interviewing 15 participants as theoretical saturation was reached and no new insights were forthcoming (Miles \& Huberman, 1994; Strauss \& Corbin, 1998). Demographic information is provided in Table 1 for the participants included in the final sample.

Table 1

Participant Demographics

\begin{tabular}{|c|c|c|}
\hline $\begin{array}{l}\text { Number of Participants } \\
\text { in Study }\end{array}$ & \multicolumn{2}{|l|}{15} \\
\hline $\begin{array}{l}\text { Various Positions Held } \\
\text { by Participants }\end{array}$ & \multicolumn{2}{|c|}{$\begin{array}{l}\text { CEO, President, COO, Senior Vice President, Director, } \\
\text { Managing Director, Managing Partner, Principal \& Partner }\end{array}$} \\
\hline $\begin{array}{l}\text { Range of Years Spent by } \\
\text { Participants at Current } \\
\text { Organizations }\end{array}$ & $\begin{array}{l}\text { Tenure Ranges from } 2-34 \text { y } \\
\text { Years Spent at Firm: } \\
\text { Less than } 5 \text { years: } \\
\text { Between } 5 \& 10 \text { years } \\
\text { Between } 10 \& 20 \text { years } \\
\text { Over } 20 \text { years }\end{array}$ & $\begin{array}{l}4 \text { Participants } \\
5 \text { Participants } \\
3 \text { Participants } \\
3 \text { Participants }\end{array}$ \\
\hline $\begin{array}{l}\text { Range of Revenues } \\
\text { (in thousands) for } \\
\text { Participants' } \\
\text { Organizations }\end{array}$ & $\$ 450-\$ 4,995,000$ & \\
\hline $\begin{array}{l}\text { Range of Employees } \\
\text { Employed at } \\
\text { Participants' } \\
\text { Organizations }\end{array}$ & $3-16,000$ & \\
\hline
\end{tabular}

Data Gathering

Data was primarily gathered during two semi-structured interviews with participants, which were digitally recorded and transcribed. The goals of the first meeting were to elicit a competitor set for each participant's organization with the firms ordered from closest competitor to most distant, complete the repertory grid technique, and interview each participant regarding 


\section{IDENTITY, COMPETITORS AND DISTINCTIVENESS}

the firms identified as competitors. The goals of the second meeting were to surface each participant's organizational identity, determine if it was connected to the participant's repertory grid, and ask additional interview questions about the data surfaced in the first interview.

The minimum context version of the RGT was used to produce a repertory grid for each participant (Fransella et al., 2004). When utilizing this procedure, the names of each firm identified as a competitor were recorded on an index card. Then two of these index cards were selected at random and presented to the participant along with another card that contained the name of the participant's organization. The participant was then asked in reference to these three index cards: How are two alike in some way, but different from the third? In responding to this question, a construct was elicited. This procedure was repeated to the point where participants could not generate additional constructs.

Each participant's final repertory grid comprised a series of bipolar constructs ( ie.e, concepts or attributes), which collectively represent how each participant construed his or her organization's competitors. The bipolar quality of the constructs suggests that individuals make sense of their organization's competitors by contrasting how their organization and their organization's competitors are similar and different from each other (Fransella et al., 2004). For illustration purposes, Table 2 provides the repertory grid surfaced for Participant 5 (P5), which represents his cognitive framework for construing his organization and its competitors. As depicted, a bi-polar construct surfaced from P5 was fee-based/commission. Together, these two attributes capture P5's perception that competitors differ in the philosophy they employ when charging for investment advice. In explaining his perceptions of this construct, P5 indicated that a firm that is fee-based can be more objective about which investments are recommended to a client because the firm's compensation remains the same regardless of which investment product is recommended; while a firm that is compensated solely on commissions is less objective, since its compensation can be enhanced by selling certain investments.

According to repertory grid theory, P5 considers fee-based and commission compensation to be opposites of each other. Moreover, this participant, in part, gains an understanding of his competitors by positioning them along the dimension of this fee-based/commission construct. As depicted in his repertory grid, P5 located his own organization and each competitor on this construct by assigning a rating to each firm using a 7-point Likert scale. The more that the given rating is closer to 1 , the more that $\mathrm{P} 5$ considers the firm to be fee-based in its compensation and thus, more objective in its investments recommendations. In contrast, the more that a firm receives a rating closer to 7 , the more that P5 characterizes the firm as charging clients solely based upon commissions and thus, more biased in its investment recommendations. As for the rest of the constructs in the grid, they collectively provide a cognitive representation as to how P5 views each one of the firms depicted.

To elicit a description of each participant's organizational identity, cognitive mapping procedures were adopted from Dutton and Dukerich (1991). Because organizational identity is often deeply embedded (Albert \& Whetten, 1985; Ashforth \& Mael, 1996), the following statement was read to participants:

Organizational identity captures the idea that employees of an organization can provide an answer to the question, 'Who are we?' In 


\section{IDENTITY, COMPETITORS AND DISTINCTIVENESS}

other words, it has been shown that employees, through their association with their organizations, will develop their own answer to this question. Moreover, researchers suggest that the answer to the identity question 'Who are we?' - will point to the essence of the organization, what is truly important, why the organization exists and how it is distinctive from other organizations.

Table 2

P5's Repertory Grid (ratings assigned by P5)

\begin{tabular}{|c|c|c|c|c|c|c|c|c|c|c|c|c|c|c|}
\hline$\underline{\text { Constructs }}$ & & & U & $\tilde{U}$ & ப் & שี & $\dot{v}$ & $\tilde{U}$ & రొ & $\hat{\vartheta}$ & $\stackrel{\theta}{\underline{v}}$ & $\bar{v}$ & ขี & Constructs \\
\hline Fee-Based & 1 & 4 & 1 & 3 & 1 & 1 & 1 & 5 & 5 & 5 & 5 & 7 & 7 & Commission \\
\hline $\begin{array}{l}\text { Non-Proprietary } \\
\text { Products }\end{array}$ & 1 & 1 & 1 & 2 & 1 & 6 & 6 & 4 & 4 & 4 & 2 & 2 & 7 & Proprietary Products \\
\hline Financial Planning & 1 & 1 & 1 & 2 & 7 & 5 & 5 & 3 & 3 & 3 & 6 & 7 & 2 & $\begin{array}{l}\text { Investment } \\
\text { Management }\end{array}$ \\
\hline Customize & 1 & 1 & 1 & 1 & 7 & 7 & 7 & 5 & 5 & 5 & 5 & 5 & 6 & Standardization \\
\hline $\begin{array}{l}\text { High Name } \\
\text { Recognition }\end{array}$ & 3 & 3 & 3 & 3 & 3 & 1 & 1 & 1 & 1 & 1 & 7 & 5 & 2 & Low Name Recognition \\
\hline Not Captive & 1 & 1 & 1 & 1 & 1 & 3 & 3 & 3 & 3 & 3 & 3 & 3 & 1 & $\begin{array}{l}\text { Narrow Captive } \\
\text { Product }\end{array}$ \\
\hline Low Cross Selling & 1 & 1 & 1 & 1 & 1 & 7 & 7 & 7 & 7 & 7 & 5 & 5 & 1 & High Cross Selling \\
\hline Pure Investments & 1 & 1 & 1 & 1 & 1 & 6 & 6 & 7 & 7 & 7 & 5 & 5 & 2 & Supermarket \\
\hline
\end{tabular}

Note: Constructs linked to OI are denoted in italics.

Subsequently, the participant was asked to describe his or her OI with the following question: Who is (fill in the name of participant's organization)? If the participant had difficulty answering or if further clarification was needed about the participant's identity description, the participant would then be asked, What are your organization's core values? If the core values were identified, the participant was also asked whether such values provided a means to answer the identity question: Who are we as an organization? At the conclusion of this process, the researcher's understanding of the elicited OI description was verified by the participant.

Next, each participant's identity description was delineated into substantive and intangible components. According to Gustafson and Reger (1995: 464), substantive identity attributes are more "concrete" or tangible organizational characteristics such as "products, strategies, geographic scope, or core competencies." In contrast, intangible identity attributes are more "abstract" organizational characteristics that "describe how and why things are done" and which "establish the context for the organization" (Gustafson \& Reger, 1995: 464). 


\section{IDENTITY, COMPETITORS AND DISTINCTIVENESS}

Gustafson and Reger (1995: 464) assert that these types of characteristics "tend to be reflected in the organizational culture and underlying values that transcend any particular product, process, time or environment."

Once OI descriptions were surfaced and delineated, participants were then asked to review their respective repertory grid results and identify which grid constructs, if any, were connected to, or in some way captured, the essence of their respective organizational identities. Participants were further interviewed about this connection, their RGT results, and their OI descriptions in order to determine how they construe their OID.

\section{Data Analysis}

$\begin{array}{lll}1^{\text {st }} \text { Order Codes } & 2^{\text {nd } \text { Order Codes }} & \text { Axial Codes } \\ \text { (Concepts } & \text { (Catagories) } & \text { (Themes) }\end{array}$

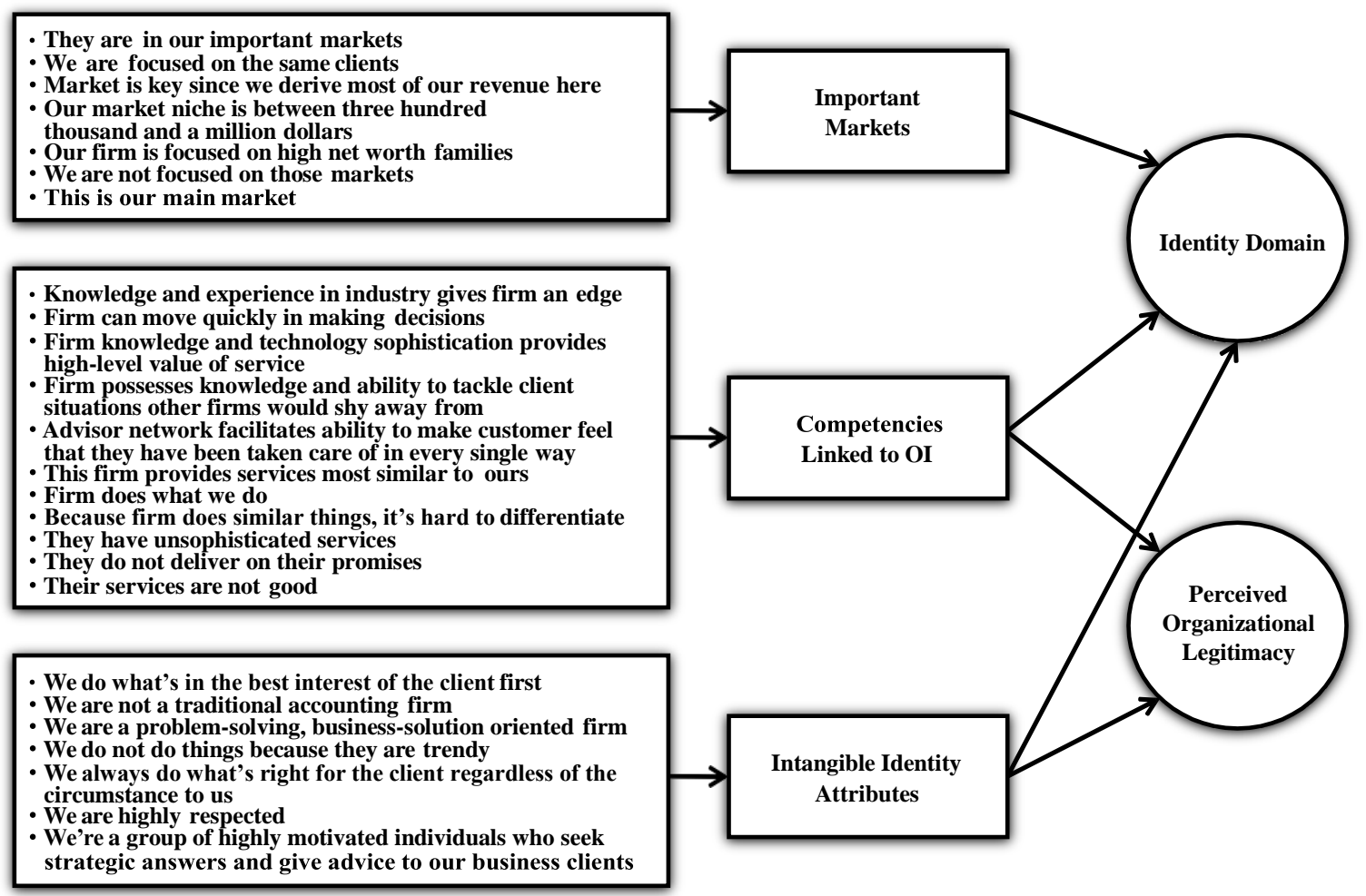

Figure 1. Data Structure

Data analysis was conducted in two phases. First, in the coding phase, interview transcripts were analyzed using micro-analytic coding procedures (Strauss \& Corbin, 1998). Such procedures necessitate a detailed, word-by-word analysis of the transcripts to unearth the potential array of meaning being communicated by a participant. As a result of this process, a set of first-order codes (or concepts) surfaced which were assigned to segments of the interview transcripts to label the various concepts mentioned by the participants. These first-order codes were developed by either paraphrasing or utilizing the participant's own words. As the firstorder codes collected, they were organized and grouped into higher-order categories, which 


\section{IDENTITY, COMPETITORS AND DISTINCTIVENESS}

reflected the interpretations of the emerging concepts. These higher-order categories were then labeled with descriptive, second-order codes. Subsequently, axial coding - a process whereby the second-order codes are examined for associations or connections and labeled accordingly was also performed. The data structure - first-order, second-order and axial codes - which emerged from these efforts is depicted in Figure 1.

Next, in the analysis phase, meta-matrices were constructed for each participant. These matrices facilitated the ability to analyze the emerging data structure across the 15 participant cases and ultimately produce the final theoretical framework (Miles \& Huberman, 1994). More specifically, a replication strategy was employed in which the developing theory was refined by repetitively returning to the gathered data, comparing it to the emerging theory, making any necessary adjustments to the theory, comparing the newly adjusted theory to the data again, and repeating the cycle. In the end, a theoretical framework which was grounded in the data and that best fit each case was produce (Eisenhardt, 1989). This framework is depicted in Figure 2.

To enhance the reliability of the data analysis, the help of an experienced independent researcher was recruited to evaluate the authenticity of the coding system. The inter-coder reliability rating results were above $80 \%$, verifying the reliability of the coding scheme. In addition, to manage and examine the 400 plus pages of interview records transcribed, Atlas.ti - a qualitative data management software package - was utilized. Furthermore, to confirm the understanding and interpretation of the data gathered, follow-up interviews were held with nine of the original participants. The results of all these efforts are reported next.

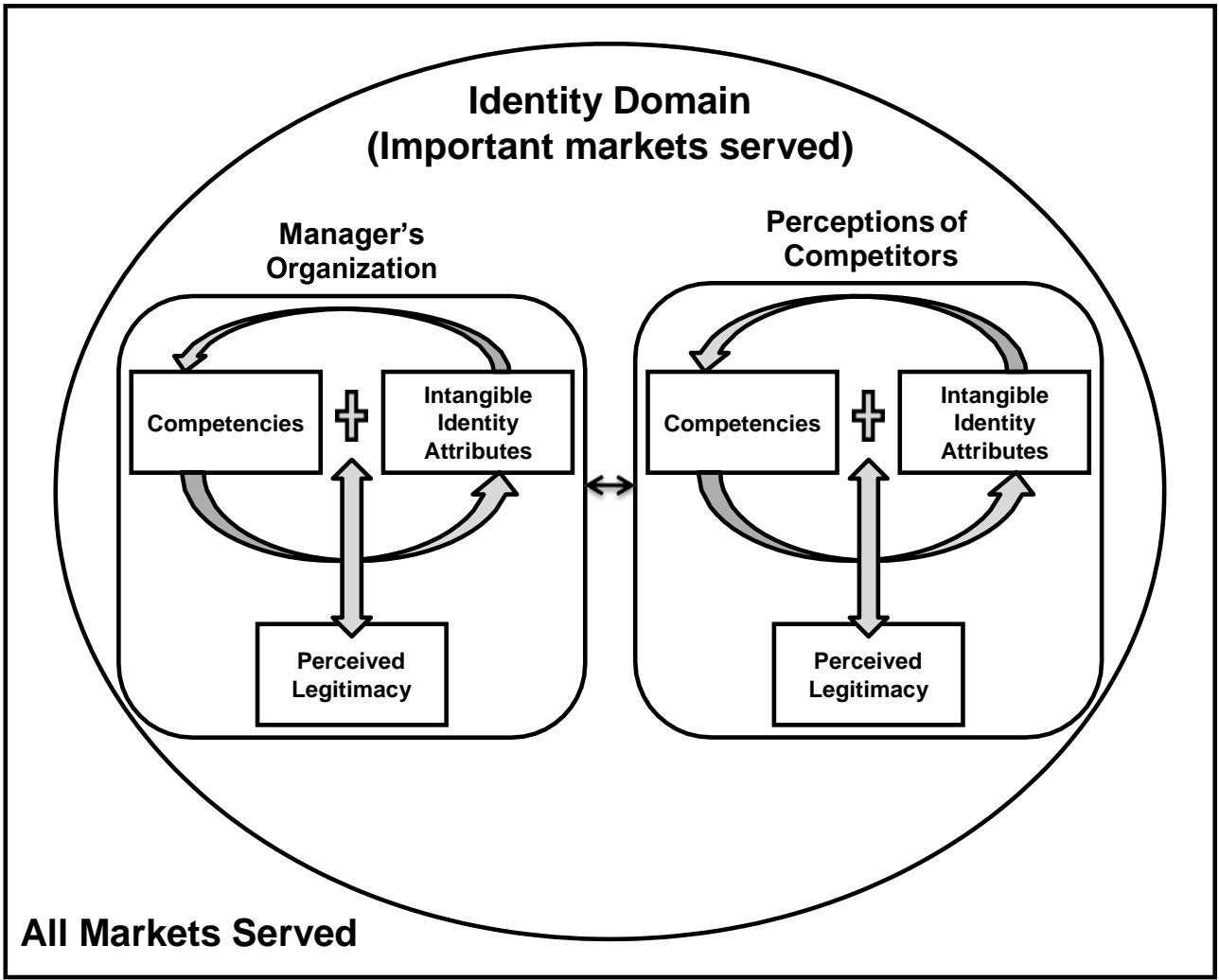

Figure 2: Model of OID 


\section{IDENTITY, COMPETITORS AND DISTINCTIVENESS}

\section{Results}

All participants linked their respective repertory grids to their OI narratives by identifying certain grid constructs as embodying aspects of their respective OIs (hereafter, the identity constructs). This result is important result for several reasons. First, since the repertory grids depict how participants construe their own organization and its competitors, this finding supports the notion that competitors play a role in how managers construe their organization's sense of identity (Corley, 2004). Second, the identity constructs capture the dimensions of comparison that were used by participants to establish their organization's OID. Third, the numerical ratings assigned to the participant's organization and competitors along the identity constructs, and each participant's subsequent explanation for these ratings, provided the means to surface and examine each participant's OID narrative and develop the final theoretical model.

Accordingly, the theoretical model depicted figure 2 that surfaced from this analysis will be discussed in remainder of this section. The main goals of this discussion will be to reveal the analysis that lead to the theoretical framework, provide specific examples to illustrate how we arrived at our conclusions and where appropriate ground the theoretical model to existing theory. Please note that to safeguard the identities of participants and the various firms mentioned, participants are labeled P1, P2, and so on. Likewise, competitors identified and ranked by each participant are referred to as $\mathrm{C} 1, \mathrm{C} 2$ and so on, with $\mathrm{C} 1$ being the organization's closest competitor, $\mathrm{C} 2$ the next closest, and so forth until all named competitors are listed in the order they were ranked.

\section{Markets}

With respect to markets, two main findings are reported. First, all of the participants used conceptions of the markets that their organizations serve as one of the means to construe and evaluate their OID. In support of this contention, it is offered that all of the participants made a reference to a specific customer segment or market in their OI descriptions. In addition, five of the fifteen participants connected their organizational identities to certain market based constructs of their repertory grids. For participants, the consistent presence of markets (or customer segments) in their identity statements suggests that the customer stakeholder group was influential in forming participants' perceptions of their OID (S. G. Scott \& Lane, 2000).

Second, only markets that were deemed important to the organization were connected by participants to their OIs. As depicted in figure 2, the square space represents All Markets Served by an organization, which highlights our finding that many of our participants operated in multiple market spaces. However, we found that the important markets upon which an organization is focused served as the main forum or the identity domain where the OID was constructed (Livengood \& Reger, 2010). This is captured by the Identity Domain oval in figure 2. According to participants, important markets are financially significant to the organization and/or are ones in which the participant's organization tends to consistently focus its efforts and resources on soliciting additional customers or business. Accordingly, participants largely ignored their unimportant market segments and used their organization's important markets as an identity domain to construct their organization's OID. 


\section{IDENTITY, COMPETITORS AND DISTINCTIVENESS}

For example, $\mathrm{P} 15$ 's organization is a bank that provides various financial and banking services to both the individual and business markets. However, despite operating in multiple markets, P15 only connected his organization's identity to the small business market. The following excerpt from P15's identity narrative illustrates this connection:

I would say that [we are] a financial services company with an expertise around the small business....In other words, we're not just a bank. We offer banking. We offer investment management. We offer insurance. We offer armored transport. We offer services uniquely designed around the small business....

Additionally, with respect to his repertory grid, P15 connected his sense of identity to the Small Business Focus - Individual Focus market based construct. Thus, the small business market represents the identity domain of P15's organization. Consequently, not all markets were involved in P15's interpretation of OID; instead, only the important markets - those comprising the identity domain - affected how P15 construed his OID.

Based on these findings, we offer the following proposition:

\section{P1: The more important a market is to an organization, the more likely the market will serve as the identity domain through which an organization's OID is constructed.}

\section{Sources of Competitive Advantage (Competencies)}

Each participant's grid contained competence constructs that described core organizational activities that facilitate the ability to produce a product which provides value to customers in the organization's identity domain (Wernerfelt, 1984) and play a critical role in the organization's ability to attain a competitive advantage (Barney, 1991). The presence of competency constructs in participants' repertory grids is not surprising given that competencies play an important role in how managers construe competitive relationships (i.e., competitive tension) (Chen, 1996). More importantly, all participants identified certain competency constructs as being related to his or her organization's identity. Again, the inter-relationship between the participants' OI narrative and competencies is also understandable since competencies can serve as a means to define an organization (Gustafson \& Reger, 1995; Ravasi \& Canato, 2010). Accordingly, the presence of competence/identity constructs in participants' repertory grids indicates that participants employed competencies as dimensions of comparison for purposes of constructing their OID.

However, the results of this study suggest that this competency assessment alone does not fully explain how participants construe their OID. Instead, participants also evaluated competencies - both their own and those of their competitors - based upon their own organization's intangible identity attributes. First, with respect to their own organizations, participants referenced their intangible identity characteristics - abstract concepts (such as core values, purpose, mission, etc.) which tend to represent those fundamental and deep rooted aspects of an organization's identity (Corley et al., 2006) - in order to justify and explain the meaning or importance of their organizations' chosen position on each competence/identity construct. This finding is consistent with the theoretical interrelationship between an organization's competencies and intangible identity attributes (Ashforth \& Mael, 1996; Gustafson \& Reger, 1995), such that competencies provide the means to enact the intangible 


\section{IDENTITY, COMPETITORS AND DISTINCTIVENESS}

identity attributes and these attributes, in turn, are constructed or reconstructed in light of the competencies.

The inter-relationship between Competencies and Intangible Identity Attributes depicted in Figure 2 is important as it enhances and enriches participants' understanding of their own organization's competence/identity constructs. Additionally, this enhanced understanding functions as a combined reference point. More specifically, the results suggest that participants partly determined their OID within the identity domain by analyzing where a competitor stands in light of their own organization's competencies and intangible identity components. The inclusion of intangible identity features into the OID evaluation process produces a more meaningful distinction than that which would arise from a strict comparison of competencies. As such, competitors are not only evaluated in terms of differences in activities but also in terms of differences in central and enduring attributes - values, mission, aspirations, etc. Moreover, this combined reference point provided the basis to construe the organization's perceived legitimacy, which the findings propose is the remaining factor in explaining how managers interpret OID.

\section{Perceived Organizational Legitimacy}

The results support the notion of legitimizing feedback (Gioia et al., 2010) in which participants held beliefs about what customers actually think about the legitimacy of the claimed OID. There are three important points to note about this finding concerning organizational legitimacy. First, this notion of legitimacy stems from the perspective of the participant and concerns what the participant thinks others believe about differences between the organization and its competitors. Thus, this notion of perceived organizational legitimacy (POL) does not necessarily involve perceptions actually held by external stakeholders (i.e., the organization's reputation). Second, the organization's combined reference point - which is comprised of its core competencies and intangible identity attributes - was aligned with participant's beliefs of what customers within the organization's identity domain consider to be legitimate and appropriate (this is depicted in Figure 2 through an interactive arrow between the Competencies and Intangible Identity Attributes and Perceived Legitimacy within the Manager's Organization). This combined reference point not only represents what participants want others to think about their organizations (i.e., their intended images), but it also represents participants' beliefs as to why customers view their organizations as legitimate. Third, participants perceived that customers evaluate the extent to which their organization and its competitors are legitimate. Since the competencies and intangible OI components capture a participant's belief as to why customers view the organization to be legitimate, participants perceived that competitors who differed along these components would be evaluated as less legitimate or appropriate (see Figure 2). In turn, the resulting perception that their organization is more legitimate and appropriate than competitors provided participants with the means to construe their OID.

Overall, these findings are consistent with prior research that has established a connection between OI and legitimacy (Dutton \& Dukerich, 1991; Dutton \& Penner, 1993; Gioia et al., 2013; He \& Baruch, 2010); demonstrated that organizational members' sense of OI is influenced by how the organization is viewed by external stakeholders (Dutton, Dukerich, \& Harquail, 1994; S. G. Scott \& Lane, 2000); and suggested that factors used to 


\section{IDENTITY, COMPETITORS AND DISTINCTIVENESS}

establish an organization's legitimacy with its external stakeholders can also be used to establish an organization's distinctiveness (Deephouse \& Carter, 2005; Gioia et al., 2013; Glynn, 2008; Zuckerman, 1999). As illustrated in the next two sub-sections of this paper, the data revealed that competence and intangible OI distinctiveness provided the participants' organizations with perceived pragmatic legitimacy in which participants expressed beliefs that their organizations did a better job than competitors of meeting the self-interested needs of its customers and/or with perceived moral legitimacy in which participants believed that their organization is more ethical and principled than its competitors (Suchman, 1995).

\section{Perceived Pragmatic Legitimacy}

Consistent with the notion of pragmatic legitimacy, the findings suggest that one way managers evaluate their organization's appropriateness is by whether the organization produces a better product than its competitors. In fact, participants referenced this desire to produce a better product in order to provide a higher level of value to customers when explaining why their competence constructs were connected to their OIs. In essence, participants' perceptions as to whether they produce a better product are based, in part, upon their intangible identity components.

Table 3

P4's Repertory Grid

\begin{tabular}{|c|c|c|c|c|c|c|c|}
\hline \multirow[b]{2}{*}{ Constructs } & & & & & & & \multirow[b]{2}{*}{ Constructs } \\
\hline & $\begin{array}{c}\Xi \\
\vdots \\
\vdots \\
\vdots \\
\pm \\
\pm\end{array}$ & $\bar{U}$ & U & $\tilde{U}$ & ப & ש & \\
\hline $\begin{array}{l}\text { Large Scope of } \\
\text { Capabilities }\end{array}$ & 3 & 2 & 1 & 3 & 5 & 5 & $\begin{array}{l}\text { Small Scope of } \\
\text { Capabilities }\end{array}$ \\
\hline Healthcare & 2 & 5 & 1 & 6 & 7 & 6 & No Healthcare \\
\hline Non-Profit & 1 & 5 & 3 & 7 & 7 & 7 & No Non-Profit \\
\hline Strong Tax Practice & 3 & 1 & 2 & 4 & 5 & 4 & Weak Tax Practice \\
\hline $\begin{array}{l}\text { Strong/Tight Alliance } \\
\text { Relation }\end{array}$ & 2 & 5 & 7 & 5 & 1 & 7 & $\begin{array}{l}\text { Weak/Loose Alliance } \\
\text { Relation }\end{array}$ \\
\hline Present Global Image & 5 & 5 & 3 & 5 & 2 & 7 & $\begin{array}{l}\text { Not Present Global } \\
\text { Image }\end{array}$ \\
\hline $\begin{array}{l}\text { High Client } \\
\text { Concentration }\end{array}$ & 1 & 1 & 1 & 3 & 4 & 7 & $\begin{array}{l}\text { Low Client } \\
\text { Concentration }\end{array}$ \\
\hline Aggressive & 2 & 1 & 4 & 3 & 4 & 2 & Non-aggressive \\
\hline $\begin{array}{l}\text { High Understanding of } \\
\text { the Role of Commodity } \\
\text { and Consulting } \\
\text { (Philosophy) }\end{array}$ & 1 & 1 & 1 & 3 & 5 & 5 & $\begin{array}{l}\text { Low Understanding of } \\
\text { the Role of Commodity } \\
\text { and Consulting } \\
\text { (Philosophy) }\end{array}$ \\
\hline
\end{tabular}

Note: Constructs linked to OI are denoted in italics.

For example, P4 identified two important markets which are financially significant to his organization: the healthcare and non-profit markets. Since both of these markets appeared as 


\section{IDENTITY, COMPETITORS AND DISTINCTIVENESS}

constructs in P4's repertory grid and were connected to his identity statement, they represent the collective identity domain of P4's organization. (See Table 3 for P4's repertory grid). Even though P4's organization also competed in the tax compliance market, P4 ignored this market when construing his organization's identity, indicating that this market does not play a role in forming his firm's identity.

Additionally, the following excerpt from P4's OI description illustrates other defining characteristics of his organization:

We are a highly respected, dedicated to customer/client quality, growth and profit driven organization...[W]e want to be the best firm in the city. And as long as we can be the best firm in the city at everything we do - and that doesn't mean we have to do everything that other firms do - but as long as we are the best at what we do, everything else will be fine.... [We want to] be well respected, so then everything falls out around that. So you can't treat your employees unfairly and end up being well respected. That just doesn't work; it's a contradiction. You can't be well respected and gouge your customers. You can't be well respected and have clients that are unethical.

P4 connected these intangible identity components - being highly respected, dedicated to customer/client quality and the best firm in the city - to two constructs of his repertory grid: Non-profit and Healthcare. As explained by P4, these two constructs not only denote the fundamental markets of his organization, but also represent two vital competencies: the extent to which a firm has developed the ability and the depth of experience to solve sophisticated client problems or issues within the respective market or identity domain. It is important to note that P4's understanding of these constructs is enmeshed with, and has been enhanced by, his intangible identity attributes. For example, P4 describes the connection between his intangible identity attribute of being "highly respected" and the two competency constructs as follows:

Highly respected...there's a vertical perspective to experience, and we've got that vertical perspective...there are firms...monkeying around in the health care industry that can do some valuations. But then, when you really look at what they can do, and it goes down about that far, one or two layers, and then if you look at our health care practice over the last decade, you see that we can do this layer, and this layer, and this layer, and this layer, and that's what we look like. So that when you look at who we are and what we are, the fabric of what we are in the health care industry and the non-profit industry, as examples, there are deep layers of expertise. And so there is no question in my mind that in the nonprofit industry, we are one of the most respected firms in the city. There's no question in my mind that in the health care industry, we're one of the most respected firms that play in that arena.

As illustrated by this discussion, $\mathrm{P} 4$ construes his organization and its competitors in terms of his combined OI reference point - the competence constructs and intangible identity attributes. Additionally, as described by P4, these two competency constructs enact his organization's sense of being highly respected. In turn, P4 justified developing the depth of capabilities in the health care and non-profit arenas by suggesting that such expertise and depth 


\section{IDENTITY, COMPETITORS AND DISTINCTIVENESS}

is required in order to be highly respected, dedicated to customer/client quality, and the best firm in the city. Moreover, as a result of his combined OI reference point, P4 believes that his firm is more highly respected than its competition as it can provide more knowledgeable solutions - a better value - for the client. Thus, P4 perceives his firm to be more legitimate than others in the health care and non-profit arenas and a better choice for customers in his organization's identity domain. Consequently, this notion of perceived legitimacy provides $\mathrm{P} 4$ with another means to construe his OID.

Based on these findings, we offer the following proposition:

P2: An organization's members will perceive greater OID to the extent that they perceive that customers who define their identity domain consider the organization to be more pragmatically legitimate than the organization's competitors.

\section{Perceived Moral Legitimacy}

Congruent with Suchman's (1995) theory, participants' identity narratives also contained statements related to "having the customer's best interests at heart" or being "more honest" or "more ethical." In turn, participants referenced these attributes as a way to explain their organizations' preferred positions along their competence constructs. This finding suggests that managers will also construe OID, in part, by determining that their organization is more ethical or principled than their competitors.

For example, P5 describes his organization's target market as "individuals who want [investment] guidance." P5 indicates that his organization "look[s] heavily for individual investors and attract[s] them." As the organization's only market, it operates as the organization's identity domain.

Moreover, the following excerpt from P5's OI description portrays other defining attributes of his organization:

We'll always act on behalf of the client. [However, it] has to be mutually beneficial....[Y] ou can't have a one-sided transaction. [If only] we benefit, the client is hurt or is not helped...[if] the client gets all the benefit, and we get none, then we're quickly out of business....[S]o it has to be a mutually beneficial transaction wherein we're acting in the best interest of the client. And the other core value is - as much as possible - to factor out conflicts of interest, which is in part, really another way of saying the first [we are acting in the best interest of the client].

P5 linked these intangible identity components - being unbiased, acting on behalf of the client's best interest, creating mutually beneficial relationships with clients, and being authentic (his organization does what it says it is going to do) - to two constructs of his repertory grid: Fee-based and Non-proprietary products (See Table 2 for P5's repertory grid). When asked to explain the relationship between his organization's identity and the Fee-Based competency construct of his repertory grid, P5 connects being fee-based to the moral notions of being unbiased, acting on behalf of the client and being authentic:

[I]f I'm fee-based, then the client is paying me for my investment management and my expertise, not paying me for salesmanship. So 


\section{IDENTITY, COMPETITORS AND DISTINCTIVENESS}

therefore I'm not selling the client on a product [in which] I may have an interest. I'm choosing the product, the investment vehicle, that's appropriate to the client and his or her or their situation. So that allows me to be unbiased. Fee-based allows me to be unbiased and authentic in my management.

With respect to the fee-based competency construct, P5 contrasts his organization which charges fees for its investment advice with firms whose clients pay a commission for "salesmanship." In so doing, P5 believes that his organization is best positioned to offer unbiased investment guidance, as its own compensation does not depend upon which investments are recommended to and ultimately purchased by the client. In contrast, firms that receive commissions are compensated based upon which investment is actually purchased by a client. Given that commission compensation can vary widely, P5 believes that it may often, inappropriately, be a factor in the advice provided by a firm.

In describing the Non-Proprietary Products identity construct, P5 references the intangible notions of being unbiased and working on behalf of the client:

If I had proprietary products, then I will always see those products as appropriate for my client, whether they are or not. [In addition,] I will probably never tell my clients that they later have become inappropriate or that they are underperforming. But if it's nonproprietary, then I'm free and un-conflicted and [I will] work in the best interest of the client....

P5 suggests that his organization is distinct from those firms which sell proprietary products in that these firms will "always see" their products as being "appropriate" for the client "whether they are or not." From P5's viewpoint, the firms which sell proprietary products have a conflict of interest and are not acting in the best interest of the client - unlike his organization.

As demonstrated in this example, the intangible aspects of P5's OI description combine with the organization's competencies - or substantive identity components - to depict what is uniquely important to his organization. Moreover, these intangible OI aspects serve as a basis for P5 to validate his organization's preferred location on each competency construct, while also enhancing P5's evaluation of his organization's competitors with respect to these same sources of competitive advantage. Finally, as a result of this combined OI reference point, P5 judges his organization to be better than its competition at putting the clients' best interests first, which makes P5's organization a more appropriate choice for it clients. Thus, this perception of moral legitimacy provides P5 with another means to construe his OID.

Based on these findings, we offer the following proposition:

P2: An organization's members will perceive greater OID to the extent that they perceive that customers who define their identity domain consider the organization to be more morally legitimate than the organization's competitors.

\section{DISCUSSION}

As stated earlier, it was hoped that exploring OID at the individual level of analysis would provide the ability to glean insights regarding the social processes of organizational 


\section{IDENTITY, COMPETITORS AND DISTINCTIVENESS}

identity work that members engage in when constructing and reconstructing the OID. Accordingly, we offer the following implications of this study and its results.

First, the results suggest that organizational identity work requires that members socially construct and negotiate the organization's identity domain. Given that identity domains comprise the organization's important markets, internal cues - e.g., percentage of revenue derived from various markets served; success indicators such as market share, growth rate, etc.; length of time that various markets have been served; the resources that have been devoted to these markets will function as indicators or referents members will use to craft a plausible narrative which segment the important, identity domain markets form the lesser important, non-identity domain markets. Given the need to make such a distinction, one could argue that the end result is an organization comprised of majority and minority groups. For example, one would expect that within P15's organization those divisions/departments/groups that play an important role in serving the organization's identity domain - the small business market - would be viewed as more important than those who serve the other less important markets.

Accordingly, such internal distinctions will confer higher status to certain groups while relegating other groups to lower status. Overall, one implication of our findings is that organizational identity work may entail not only interactions among individuals but also may reflect processes of intergroup conflict between members as they seek to improve the status of their group (Bettencourt, Charlton, Dorr, \& Hume, 2001; Dovidio \& Gaertner, 2010).

Second, an identity domain provides a stable set of reference points - markets (customers) and competitors - necessary to construct OI. In other words, an enduring and distinct identity would be near impossible to construct in the face of shifting reference points. With respect to organizational identity work, the identity domain's role as a stable reference point enhances current theory related to the enduring nature of OI (Gioia et al., 2013; Gioia, Schultz, \& Corley, 2000). In short, OI can be destabilized, and identity change may occur, when an organization faces circumstances that require a change in reference points, such as the unexpected presence of different or new competitors or when the organization must abandon important markets and enter new ones.

Third, existing theory suggests that $\mathrm{OI}$ is socially constructed through internal as well as external interactions between the organization and its stakeholders (Gioia et al., 2000; Hatch \& Schultz, 2002). At the center of these interactions is the organization's desire to be viewed by stakeholders as legitimate. In order to attain legitimacy, organizations will project their identities into the external environment in an effort to shape stakeholder impressions or, in the case where stakeholders do not consider the organization to be legitimate, may adjust their OIs. However, this study provides additional support for the notion of legitimizing feedback by suggesting that an organization's members not only want to be viewed by stakeholders as legitimate, but also more legitimate than their closest competitors. Accordingly, the competencies and intangible OI attributes comprise the organization's intended image - what managers want customers in the identity domain to believe about the organization in relation to its competitors (T. J. Brown, Dacin, Pratt, \& Whetten, 2006) - which will be projected into the identity domain in order to shape customers' impressions that the organization is more legitimate than its competitors. In turn, although not the subject of this study, customers 


\section{IDENTITY, COMPETITORS AND DISTINCTIVENESS}

should reflect back to the organization their beliefs as to whether the organization has configured its competencies and intangible OI components in a more legitimate manner.

Fourth, the results of this study also suggest that managers' construed image may be constructed in a biased or self-interested manner (Gioia et al., 2013; Martin, Feldman, Hatch, \& Sitkin, 1983). Because participants considered differences between their organization's competencies and intangible OI attributes as indicating that their competitors were less legitimate, our study suggests that managers believe that customers not only view their organization as legitimate, but also evaluate the extent of the organization's legitimacy in relation to its competitors. Inherent in this belief is that the managers' organization sets the ideal standard when it comes to legitimacy and appropriateness within the identity domain. This view is consistent with that of Brown (1997) who suggests that establishing the organization's legitimacy is highly important to an organization's members and that members will go to great lengths to establish and maintain the organization's legitimacy.

Fifth, the interrelationship between the competencies and the intangible identity components also sheds some light on the concept of centrality in OI. Centrality implies that an organizational identity captures deep rooted traits that capture the "soul" of the organization (Corley et al., 2006). According to the present study, intangible identity components represent deep or highly central aspects of an organization's identity. This notion is supported by the findings that competence distinctiveness alone was not sufficient enough to explain OID. In other words, while competencies can serve to distinguish the organization by providing it with a competitive advantage, such distinctiveness on its own does not serve to define the organization, nor account for its OID. Instead, the intangible identity components infuse an organization's competencies with a deeper level of meaning (meaning beyond simply providing a competitive advantage) by connecting the competencies to core organizational features. This connection is significant because it provides the basis for evaluating the organization's legitimacy and justifying its distinct purpose. In short, while managers may perceive that their organization is defined by substantive features (competencies, markets, products, etc.), these features alone are not as central to their sense of $\mathrm{OI}$ as the intangible components.

Finally, the results of this study also suggest that competitive tension may be a more multifaceted concept than what current theory suggests. To begin with, extant theory predicts that managers will perceive greater competitive tension with a firm employing similar resources, because such similarity threatens the organization's competitive position (Chen, 1996). However, this explanation of competitive tension does not account for the institutional perspective's observation that an organization not only competes for an economically-based competitive advantage, but also for legitimacy (Suchman, 1995). Accordingly, the results of this study provides the basis to fill this gap by suggesting that competitive tension is also affected by managers' perceptions of a competitor's legitimacy. More specifically, this study has established that managers make sense of competitors by understanding the extent to which these firms embrace similar competencies, core values, purpose and mission as the managers' organization. Thus, a competitor with a similar identity will more than likely be perceived as a competitive threat as it will be more difficult for the organization to establish its OID and justify its reason for existence. Accordingly, such perceptions would affect perceived competitive tension and 


\section{IDENTITY, COMPETITORS AND DISTINCTIVENESS}

have an effect on inter-firm rivalry. Overall, this study provides the basis to extend current theory by suggesting that perceptions of competitive tension may also involve managers' evaluations of a competitor's legitimacy and hence, its identity.

\section{Practice Implications}

The results of this study suggest that managers construct an internal story - via markets, competencies and intangible identity attributes - that represent their perceptions of OID. This insight is significant from a practice perspective given that these stories and perceptions represent managers' subjective interpretations of their organization's identity distinctiveness. In other words, because organizational identity represents managers' and other employees' beliefs about the organization, these subjective OID interpretations are essentially claims which may or may not be supported by objective facts (Ashforth \& Mael, 1996). Thus, OID claims depend, in large part, upon how managers interpret customers' opinions and beliefs as to whether the organization is more legitimate than its competitors.

While managers perceptions of OID may accurately reflect customer beliefs, some researchers have instead hypothesized that managers may ignore or downplay information that threatens the organization's identity distinctiveness (A. D. Brown, 1997). Strategically, organizations must be distinct from their competitors to create a competitive advantage, be profitable and endure (Barney, 1991; Porter, 1980).

However, the need to maintain a positive and distinct identity may be so great that managers may unintentionally make trivial or misguided OID claims that distort the organization's perceived competitive advantage. For instance, managers may select uncommon elements (Albert \& Whetten, 1985; Elsbach \& Kramer, 1996) or unimportant dimensions that favor their own firm (Hatch \& Schultz, 2002) in order to establish the organization's distinctiveness. In short, managers, in an effort to preserve their OID, may construct stories that their organization's competencies are more unique or superior than they actually are or may construct stories which matter little to, or are not known by, customers within the identity domain. Thus, in order to make sure that a reality gap does not exist in the internal perceptions of the organization's legitimacy, managers need to check their internal perceptions against the external perceptions of the customers within the identity domain (Hatch \& Schultz, 2002). Given the necessity for organizations to be distinct from their competitors in order to construct a competitive advantage, be profitable, and survive, this reality check is imperative to avoid competitive blind spots (Zajac \& Bazerman, 1991).

\section{Limitations}

While this research has made key contributions to our understanding of OID, certain limitations should also be mentioned. First, given that the sample was drawn from the financial services industry, the results may not be generalizable to other industries. Second, the data collection procedures (interview questions and mental model elicitation) may have delved into subjects that the participants had not previously contemplated. The possibility of first-timethinking affects the test-retest reliability of a study. Finally, an additional area of concern associated with the data collection methods involves the extent to which the researcher's 


\section{IDENTITY, COMPETITORS AND DISTINCTIVENESS}

interaction with the participants may have biased the results. Qualitative research inherently requires interaction between the researcher and the object of the research. However, being aware of these concerns, specific steps were taken when designing the study to increase confidence in the findings. These steps include the following: (1) deciding to conduct a pilot study to test the effectiveness of the data collection methods; (2) using both quantitative and qualitative data collection procedures to study OID; (3) taking time during the interviews to feedback to participants the emerging understanding of their situations to assure proper interpretation; (4) using analytical methods that would prevent the reaching of premature conclusions; (5) employing a second coder at various points of the data collection process; and (6) conducting follow-up interviews with nine of the original participants to ensure proper interpretation of the data (Miles \& Huberman, 1994; Yin, 2003).

\section{Future Research}

While this study furthers our knowledge of OID, additional research avenues are available to build on its findings. First, each individual manager will have his or her own perception as to the organization's identity distinctiveness (Dutton \& Penner, 1993). However, managers' perceptions are not formed in isolation; instead, they are influenced by social interactions between top managers and other organizational members (Weick, Sutcliffe, \& Obstfeld, 2005). Thus, investigations delving into how OID is socially constructed would complement this study's findings. Second, past research has demonstrated that while OI is somewhat resistant to change, it will nevertheless change over time (Gioia et al., 2000). This research stream has provided valuable insights concerning how OI changes and affects an organization's ability to change. In an effort to extend this knowledge, studies could be conducted to understand how OID changes over time. More specifically, under what conditions does an organization change or modify perceptions of its OID and how does OID affect the organization's ability to change? Additionally, research concerning how organizations deal with situations which threaten their OID would make a valuable contribution to our new-found knowledge. While several studies have investigated how organizations respond to OI threats (Elsbach \& Kramer, 1996; Ravasi \& Schultz, 2006), no study to date has focused on how organizations deal with distinctiveness threats. Such an oversight is significant given that social psychology research has demonstrated that threats to a group's distinctiveness can lead to certain behaviors such as in-group favoritism, out-group discrimination, and in-group polarization (Haslam \& Ellemers, 2005; Turner \& Oakes, 1989). In addition, Albert \& Whetten (1985) suggest that organizations may employ uncommon dimensions of comparison in order to maintain the organization's distinctiveness. Accordingly, research needs to be conducted to more fully understand the impact that OID threats have on an organization and the various responses that organizations employ to deal with such threats. Finally, given the importance of competitors in construing OID, one could also explore how OID impacts perceptions of competition. 


\section{IDENTITY, COMPETITORS AND DISTINCTIVENESS}

\section{References}

Albert, S., \& Whetten, D. A. (1985). Organizational identity. In L. L. Cummings \& B. M. Staw (Eds.), Research in Organizational Behavior (Vol. 7, pp. 263-295). Greenwich, CT: JAI Press.

Ashforth, B. E., \& Gibbs, B. W. (1990). The double-edge of organizational legitimation. Organization Science, 1, 177-194.

Ashforth, B. E., \& Mael, F. A. (1996). Organizational identity and strategy as a context for the individual. In J. C. Baum \& J. E. Dutton (Eds.), Advances in Strategic Management (Vol. 13, pp. 19-64). Greenwich, CT: JAI Press.

Ashforth, B. E., Rogers, K. M., \& Corley, K. G. (2011). Identity in organizations: exploring cross-level dynamics. Organization Science, 22(5), 1144-1156.

Barney, J. (1991). Firm resources and sustained competitive advantage. Journal of Management, 17(1), 99-120.

Bettencourt, B. A., Charlton, K., Dorr, N., \& Hume, D. L. (2001). Status differences and ingroup bias: a meta-analytic examination of the effects of status stability, status legitimacy, and group permeability. Psychological Bulletin, 127(4), 520-542. doi:10.1037/0033-2909.127.4.520

Brewer, M. B., \& Roccas, S. (2001). Individual values, social identity, and optimal distinctiveness. In C. Sedikides \& M. B. Brewer (Eds.), Individual Self, Relational Self, Collective Self. Philadelphia, PA: Psychological Press.

Brown, A. D. (1997). Narcissism, identity, and legitimacy. The Academy of Management Review, 22(3), 643-686.

Brown, A. D. (2006). A narrative approach to collective identities. Journal of Management Studies, 43(4), 731-753.

Brown, T. J., Dacin, P. A., Pratt, M. G., \& Whetten, D. A. (2006). Identity, intended image, construed image, and reputation: An interdisciplinary framework and suggested terminology. Journal of the Academy of Marketing Science, 34(2), 99-106.

Chen, M.-J. (1996). Competitor analysis and interfirm rivalry: Toward a theoretical integration. The Academy of Management Review, 21(1), 100-134.

Clegg, S. R., Rhodes, C., \& Kornberger, M. (2007). Desperately seeking legitimacy: Organizational identity and emerging industries. Organization Studies, 28(4), 495-513.

Corley, K. G. (2004). Defined by our strategy or our culture? Hierarchical differences in perceptions of organizational identity and change. Human Relations, 57(9), 1145-1177.

Corley, K. G., \& Gioia, D. A. (2003). Semantic learning as change enabler: Relating organizational identity and organizational learning. In M. Easterby-Smith \& M. A. Lyles (Eds.), Handbook of Organizational Learning and Knowledge Management (pp. 621636). London: Blackwell.

Corley, K. G., Harquail, C. V., Pratt, M. G., Glynn, M. A., Fiol, C. M., \& Hatch, M. J. (2006). Guiding organizational identity through aged adolescence. Journal of Management Inquiry, 15(2), 85-99. doi:10.1177/1056492605285930

Cornelissen, J. P., Haslam, S. A., \& Balmer, J. M. T. (2007). Social identity, organizational identity and corporate identity: Towards an integrated understanding of processes, patternings and products. British Journal of Management, 18, S1-S16. doi:10.1111/j.1467-8551.2007.00522.x 


\section{IDENTITY, COMPETITORS AND DISTINCTIVENESS}

Deephouse, D. L. (1999). To be different, or be the same? It's a question (and theory) of strategic balance. Strategic Management Journal, 20, 147-166.

Deephouse, D. L., \& Carter, S. M. (2005). An examination of differences between organizational legitimacy and organizational reputation. Journal of Management Studies, 42(2), 329360. doi:10.1111/j.1467-6486.2005.00499.x

Dovidio, J. F., \& Gaertner, S. L. (2010). Intergroup bias. In S. T. Fiske, D. T. Gilbert, \& G. Lindzey (Eds.), Handbook of Social Psychology (5 ed., Vol. 2, pp. 1084-1121). Hoboken, NJ: John Wiley \& Sons Inc.

Dutton, J. E., \& Dukerich, J. M. (1991). Keeping an eye on the mirror: Image and identity in organizational adaptation. Academy of Management Journal, 34(3), 517-554.

Dutton, J. E., Dukerich, J. M., \& Harquail, C. V. (1994). Organizational images and member identification. Administrative Science Quarterly, 39(2), 239-263.

Dutton, J. E., \& Penner, W. J. (1993). The importance of organizational identity for strategic agenda building. In J. Hendry, G. Johnson, \& J. Newton (Eds.), Strategic Thinking: Leadership and the Management of Change (pp. 89-113). West Sussex, England: John Wiley \& Sons, Ltd.

Eisenhardt, K. M. (1989). Building theories from case study research. The Academy of Management Review, 14(4), 532-550.

Elsbach, K. D., \& Kramer, R. M. (1996). Members' responses to organizational identity threats: Encountering and countering the Business Week rankings. Administrative Science Quarterly, 41(3), 442-476.

Fiol, C. M., \& Huff, A. S. (1992). Maps for managers: Where are we? Where do we go from here? The Journal of Management Studies, 29(3), 267-285.

Fransella, F., Bell, R., \& Bannister, D. (2004). A Manual for Repertory Grid Technique (2nd ed.). West Sussex, England: Wiley.

Gioia, D. A., \& Chittipeddi, K. (1991). Sensemaking and sensegiving in strategic change initiation. Strategic Management Journal, 12(6), 433-448.

Gioia, D. A., Patvardhan, S. D., Hamilton, A. L., \& Corley, K. G. (2013). Organizational identity formation and change. Academy of Management Annals, 7(1), 123-193.

Gioia, D. A., Price, K. N., Hamilton, A. L., \& Thomas, J. B. (2010). Forging an identity: An insider-outsider study of processes involved in the formation of organizational identity. Administrative Science Quarterly, 55(1), 1-46.

Gioia, D. A., Schultz, M., \& Corley, K. G. (2000). Organizational identity, image, and adaptive instability. The Academy of Management Review, 25(1), 63-81.

Gioia, D. A., \& Thomas, J. B. (1996). Identity, image, and issue interpretation: Sensemaking during strategic change in academia. Administrative Science Quarterly, 41(3), 370-403.

Glynn, M. A. (2008). Beyond contraint: How institutions enable identities. In R. Greenwood, C. Oliver, R. Suddaby, \& K. Sahlin-Andersson (Eds.), The Sage Handbook of Organizational Institutionalism (pp. 413-430). Los Angeles, CA: Sage.

Gustafson, L. T., \& Reger, R. K. (1995). Using organizational identity to achieve stability and change in high velocity environments. Paper presented at the Academy of Management Proceedings.

Haslam, S. A., \& Ellemers, N. (2005). Social identity in industrial and organizational psychology: Concepts, controversies and contributions. In G. P. Hodgkinson \& J. K. Ford (Eds.), International Review of Industrial and Organizational Psychology (Vol. 20, pp. 39-118). West Sussex, England: John Wiley \& Sons, Ltd. 


\section{IDENTITY, COMPETITORS AND DISTINCTIVENESS}

Hatch, M. J., \& Schultz, M. (2002). The dynamics of organizational identity. Human Relations, 55(8), 989-1018.

He, H., \& Baruch, Y. (2010). Organizational identity and legitimacy under major environmental changes: Tales of two UK building societies. British journal of management, 21(1), 4462. doi:10.1111/j.1467-8551.2009.00666.x

Jetten, J., Spears, R., \& Manstead, A. S. R. (1999). Group distinctiveness and intergroup discrimination. In N. Ellemers, R. Spears, \& B. Doosje (Eds.), Social Identity: Context, Commitment, Content (pp. 107-126). Oxford: Blackwell.

Jetten, J., Spears, R., \& Postmes, T. (2004). Intergroup distinctiveness and differentiation: A meta-analytic integration. Journal of Personality and Social Psychology, 86(6), 862.

Kreiner, G. E., Hollensbe, E., Sheep, M. L., Smith, B. R., \& Kataria, N. (2015). Elasticity and the dialectic tensions of organizational identity: How can we hold together while we are pulling apart? Academy of Management Journal, 58(4), 981-1011.

Kroezen, J. J., \& Heugens, P. P. M. A. R. (2012). Organizational identity formation: Processes of identity imprinting and enactment in the Dutch microbrewing land-scape. In M. Schultz, S. Maguire, A. Langley, \& H. Tsoukas (Eds.), Constructing Identity In and Around Organizations (pp. 89-127). Oxford: Oxford University Press.

Livengood, R. S., \& Reger, R. K. (2010). That's our turf! Identity domains and competitive dynamics. The Academy of Management Review, 35(1), 48-66.

Martin, J., Feldman, M. S., Hatch, M. J., \& Sitkin, S. B. (1983). The uniqueness paradox in organizational stories. Administrative Science Quarterly, 28(3), 438-453.

Miles, M. B., \& Huberman, A. M. (1994). Qualitative Data Analysis: An Expanded Sourcebook (2nd ed.). Thousand Oaks, CA: Sage Publications.

Morrow, E. P. (2001). Are you prepared for competition? Journal of Financial Planning, 14(11), 3840.

Navis, C., \& Glynn, M. A. (2011). Legitimate distinctiveness and the entrepreneurial identity: Influence on investor judgments of new venture plausibility. Academy of Management Review, 36(3), 479-499.

Peteraf, M., \& Shanley, M. (1997). Getting to know you: A theory of strategic group identity. Strategic Management Journal, 18(Summer Special Issue), 165-186.

Porac, J. F., \& Thomas, H. (1990). Taxonomic mental models in competitor definition. The Academy of Management Review, 15(2), 224-240.

Porter, M. E. (1980). Competitive Strategy: Techniques for Analyzing Industries and Competitors. New York, NY: The Free Press.

Ravasi, D., \& Canato, A. (2010). We are what we do (and how we do it): Organizational technologies and the construction of organizational identity. In M. Lounsbury, N. Phillips, G. Sewell, \& D. Griffiths (Eds.), Technology and Organization: Essays in Honour of Joan Woodward (Research in the Sociology of Organizations) (Vol. 29, pp. 49-78). Bingley, UK: Emerald Group Publishing Limited.

Ravasi, D., \& Schultz, M. (2006). Responding to organizational identity threats: Exploring the role of organizational culture. Academy of Management Journal, 49(3), 433-458.

Reger, R. K., Barney, J. B., Bunderson, J. S., Foreman, P. O., Gustafson, L. T., Huff, A. S., . . Stimpert, J. L. (1998). A strategy conversation on the topic of organization identity. In D. A. Whetten \& P. C. Godfrey (Eds.), Identity in Organizations: Building Theory Through Conversations (pp. 99-168). Thousand Oaks, CA: Sage Publications. 


\section{IDENTITY, COMPETITORS AND DISTINCTIVENESS}

Scott, S. G., \& Lane, V. R. (2000). A stakeholder approach to organizational identity. The Academy of Management Review, 25(1), 43-62.

Scott, W. R. (2001). Institutions and Organizations (2nd ed.). Thousand Oaks, CA: Sage Publications.

Snihur, Y. (2016). Developing optimal distinctiveness: Organizational identity processes in new ventures engaged in business model innovation. Entrepreneurship \& Regional Development, 28(3/4), 259-285.

Strauss, A., \& Corbin, J. (1998). Basics of Qualitative Research (2nd ed.). Thousand Oaks, CA: Sage Publications.

Suchman, M. C. (1995). Managing legitimacy: Strategic and institutional approaches. The Academy of Management Review, 20(3), 571-610.

Turner, J. C., \& Oakes, P. J. (1989). Self-categorization theory and social influence. In P. B. Paulus (Ed.), The Psychology of Group Influence (2nd ed., pp. 233-275). Hillsdale, NJ: Erlbaum.

Weick, K. E. (1995). Sensemaking in Organizations. Thousand Oaks, CA: Sage Publications.

Weick, K. E., Sutcliffe, K. M., \& Obstfeld, D. (2005). Organizing and the process of sensemaking. Organization Science, 16(4), 409-421.

Wernerfelt, B. (1984). A resource-based view of the firm. Strategic Management Journal, 5(2), 171-180.

Whetten, D. A. (2006). Albert and Whetten revisited: Strengthening the concept of organizational identity. Journal of Management Inquiry, 15(3), 219-234. doi: $10.1177 / 1056492606291200$

Yin, R. K. (2003). Case Study Research: Design and Methods (3rd ed.). Thousand Oaks, CA: Sage Publications.

Zajac, E. J., \& Bazerman, M. H. (1991). Blind spots in industry and competitor analysis: Implications of interfirm (mis)perceptions for strategic decisions. The Academy of Management Review, 16(1), 37-56.

Zuckerman, E. W. (1999). The categorical imperative: Securities analysts and the illegitimacy discount. The American Journal of Sociology, 104(5), 1398-1439. 